\title{
Subsequent hospitalisation experience of 5-year survivors of childhood, adolescent, and young adult cancer in Scotland: a population based, retrospective cohort study
}

\author{
D H Brewster ${ }^{\star}, 1,2$, D Clark ${ }^{1}$, L Hopkins ${ }^{1}$, J Bauer ${ }^{1}$, S H Wild ${ }^{2}$, A B Edgar ${ }^{3}$ and W H Wallace ${ }^{3}$ \\ ${ }^{1}$ Information Services Division, NHS National Services Scotland, Gyle Square, 1 South Gyle Crescent, Edinburgh EH12 9EB, \\ Scotland, UK; ${ }^{2}$ Centre for Population Health Sciences, University of Edinburgh, Edinburgh, Scotland, UK and ${ }^{3}$ Department of \\ Haematology/Oncology, Royal Hospital for Sick Children, Edinburgh, Scotland, UK
}

Background: Survivors of childhood, adolescent, and young adult cancer are known to be at risk of late effects of their disease and its treatment. Most population-based studies of cancer survivors have reported on second primary cancers and mortality. The aim of this study was to research acute and psychiatric hospital admission rates and length of stay in 5-year survivors of cancer diagnosed before the age of 25 years.

Methods: This was a population-based retrospective cohort study using linked national cancer registry, acute hospital discharge, psychiatric hospital, and mortality records. The study population consisted of 5229 individuals who were diagnosed with cancer before the age of 25 years between 1981 and 2003, and who survived at least 5 years after the date of diagnosis of their primary cancer. Indirect standardisation for age and sex was used to calculate standardised bed days and hospitalisation ratios (SBDR and SHR) for both acute and psychiatric hospital admissions, and absolute excess risks (AERs) compared with the general Scottish population.

Results: Five-year survivors of cancer, diagnosed before the age of 25 years, are at increased risk of admission to acute hospitals (SHR 2.8; 95\% confidence interval 2.7-2.9) and of spending more time in hospital (SBDR 3.7; 3.6-3.7). Corresponding AERs were 6.4 (6.0-6.6) admissions and 64.8 (64.4-66.9) bed days per 100 cancer survivors per year. In contrast, 5-year survivors were not at higher risk of admission to psychiatric hospital (SHR 0.9; 0.8-1.2), and they spent significantly less time as psychiatric in-patients (SBDR 0.4; 0.4-0.4) compared with the whole population.

Conclusion: Using routinely collected linked records, our population-based study has demonstrated increased rates of hospitalisation in 5-year survivors of cancer diagnosed before the age of 25 years. Long-term clinical follow-up of survivors of cancer in this age group should focus on the prevention and treatment of the late effects of cancer in those patients at highest risk of hospitalisation.

As a result of advances in treatment, around $80 \%$ of children and young people with cancer now survive at least 5 years after diagnosis. However, around two-thirds of survivors experience at least one late effect of treatment, and around a third experiences a severe or life-threatening late effect (Bhatia and Constine, 2009). Long-term complications include second primary cancers, and effects on the endocrine, cardiac and respiratory systems, renal impairment, gastrointestinal dysfunction, musculoskeletal 
sequelae, neurocognitive dysfunction, and psychosocial manifestations (Bhatia and Constine, 2009; Edgar et al, 2009; Mulrooney et al, 2009; Recklitis et al, 2010; Brinkman et al, 2013; Lund et al, 2013; Scottish Intercollegiate Guidelines Network, 2013; Wallace et al, 2013).

There have been a number of studies of late morbidity and late mortality arising in long-term survivors of childhood, adolescent, and young adult cancer. However, most of the population-based studies have focused on mortality whereas studies of morbidity have often been conducted in selected populations of patients.

We have previously described the mortality experience of a population-based cohort of 5-year survivors of childhood, adolescent, and young adult cancer originally diagnosed between 1981 and 2003 in Scotland (Brewster et al, 2013). The aim of the present study was to describe patterns of hospitalisation as a surrogate measure of morbidity in the same cohort of patients.

\section{MATERIALS AND METHODS}

We performed a population-based retrospective cohort study to investigate acute and psychiatric hospital admission rates and length of stay in 5-year survivors of cancer diagnosed during childhood, adolescence, or early adulthood (both for all conditions combined and for specific diagnoses). Analyses were based on a national linked database, achieved by probability matching and comprising acute hospital discharge records, psychiatric hospital records, cancer registrations, and mortality records (Kendrick and Clarke, 1993). Estimates based on clerical checking suggest that rates of false positive and false negative linkages are maintained below 1\% (Kendrick, 1997). False positive and false negative links are likely to be less common nowadays because of more widespread availability and use of the Community Health Index number, a unique identifying number in Scotland. Emigrations of patients registered with cancer from Scotland to other UK countries are notified to the cancer registry by the National Health Service Central Register (NHSCR), allowing censoring of data for these individuals.

The study population comprised patients registered with the Scottish Cancer Registry who had survived at least 5 years after the diagnosis of a first cancer in childhood, adolescence, or young adulthood (age between 0 and 24 years). We included data for individuals whose year of diagnosis was in 1981 or subsequent years up to 2003.

In relation to first cancer, the study population was re-classified according to the third edition of the International Classification of Childhood Cancer (ICCC-3) (0-14 year olds) (Steliarova-Foucher et al, 2005) and the most up-to-date version of the diagnostic classification of cancer in adolescents and young adults developed by Birch et al (2002) (15-24 year olds). The data were then mapped to a common 'study classification'. As described previously (Brewster et al, 2013), this was based primarily on ICCC-3 but with separation of group XI (other malignant epithelial neoplasms and malignant melanomas) into two categories: (1) melanoma and skin carcinomas and (2) other carcinomas, excluding renal, hepatic, gonadal, and skin. Mapping of cancers in adolescents and young adults was based initially on specific morphology codes (sometimes in combination with topography codes); thereafter, the mapping was based on groups and subgroups within the Birch et al classification (see Appendix 1).

As an indicator of socio-economic position, based on postcode sectors of residence at the time of original diagnosis, individuals were assigned to fifths of Carstairs deprivation scores by applying 1981, 1991, and 2001 census-derived Carstairs scores to the periods of diagnosis 1981-1985, 1986-1995, 1996-2003, respectively. The Carstairs deprivation index is based on the small area of residence, and is derived from four variables collected at each decennial census: social class, unemployment, overcrowding, and car ownership (Morris and Carstairs, 1991).

Four main analyses defined by four main end points of interest were carried out, focussing on (1) the total number of bed days spent in acute hospitals; (2) incident cases of non-psychiatric disease-specific morbidity as defined by first ever admission to acute hospitals with particular diagnoses; (3) the total number of bed days spent in psychiatric hospitals; and (4) incident cases of psychiatric disease-specific morbidity as defined by first ever admission to psychiatric hospital with particular diagnoses. Indirectly standardised bed days ratios (SBDRs) and hospitalisation ratios (SHRs) were calculated for all diagnoses combined (SBDR and SHR) and for specific diagnoses (SHR only-see Appendix 2), using the general population as an external comparison group to generate expected numbers of bed days/ admissions (based on age-, sex-, deprivation category-, and calendar period-specific rates of in-patient bed days or diseasespecific admissions). For SBDRs, follow-up was from 5 years after diagnosis to date of emigration, date of death, or end of 2009, whichever occurred first. For SHRs, follow-up was from 5 years after diagnosis to date of first hospital admission (for a relevant diagnosis), date of emigration, date of death, or end of 2009, whichever occurred first. Absolute excess risks (AERs) were calculated as the observed minus the expected number of bed days or hospital admissions divided by the number of person-years at risk and expressed as the rate per 100 cancer survivors per year. In this context, the AER reflects the additional burden of hospitalisation beyond background levels. 95\% confidence intervals around SBDRs, SHRs, and AERs were calculated based on the assumption that the observed numbers of bed days/admissions followed a Poisson distribution. Standardised bed days ratios and SHRs with 95\% confidence intervals that did not include the value 1.0 were regarded as statistically significantly different from those observed in the general population. Cumulative incidence was estimated using the Kaplan-Meier method, and differences in cumulative incidence according to socio-economic position were assessed for statistical significance using the log-rank test.

\section{RESULTS}

From an original cohort of 6980 children and young people diagnosed with cancer in Scotland between 1981 and 2003, the study population comprised 5229 individuals who had survived for at least 5 years after the date of diagnosis of their primary cancer. Overall, beyond the point of 5-year survival, they contributed 58359 person-years of follow-up for the SBDR analyses, and 31214 and 57769 person-years of follow-up for the SHR analyses of acute hospital admissions and psychiatric hospital admissions, respectively.

In general, SBDRs (and SHRs) were little altered by standardisation for deprivation. For the sake of comparability with other studies, the results presented here are standardised for age and sex only. Overall, the study population experienced 52295 in-patient bed days in acute hospitals, yielding an SBDR of 3.7 (95\% confidence interval 3.6-3.7). This corresponds to an AER of 64.8 (64.4-66.9) in-patient bed days per 100 cancer survivors per year (observed rate 89.6 and expected rate 24.8). Standardised bed days ratios were higher in patients whose cancer was diagnosed at a young age and in patients from deprived areas of residence; they decreased with increasing follow-up time; and they varied substantially by type of primary cancer, ranging from 1.3 (1.21.3) in patients originally diagnosed with melanoma and skin carcinomas to $11.4(10.2-12.7)$ in patients originally diagnosed with hepatic tumours (Table 1). 
Table 1. Characteristics of the study population of 5-year survivors of cancers diagnosed under 25 years of age in Scotland 1981-2003, observed number of in-patient bed days beyond 5 years after their first cancer diagnosis, indirectly standardised bed days ratio (SBDR), and $95 \%$ confidence intervals (based on acute hospital discharge data and psychiatric hospitalisation data)

\begin{tabular}{|c|c|c|c|c|c|c|c|c|c|c|}
\hline \multirow[b]{3}{*}{ Characteristic } & \multirow[b]{3}{*}{$\begin{array}{c}\text { Number of } \\
\text { patients }\end{array}$} & \multirow[b]{3}{*}{$\%$} & \multicolumn{4}{|c|}{ Acute hospitalisations } & \multicolumn{4}{|c|}{ Psychiatric hospitalisations } \\
\hline & & & \multirow[b]{2}{*}{$\begin{array}{c}\text { Observed bed } \\
\text { days }\end{array}$} & \multirow[b]{2}{*}{ SBDR } & \multicolumn{2}{|c|}{$95 \% \mathrm{Cl}$} & \multirow[b]{2}{*}{$\begin{array}{l}\text { Observed } \\
\text { bed days }\end{array}$} & \multirow[b]{2}{*}{ SBDR } & \multicolumn{2}{|c|}{$95 \% \mathrm{Cl}$} \\
\hline & & & & & $\mathrm{LCl}$ & $\mathrm{UCl}$ & & & $\mathrm{LCl}$ & $\mathrm{UCl}$ \\
\hline All patients combined & 5229 & 100 & 52295 & 3.7 & 3.6 & 3.7 & 5631 & 0.4 & 0.4 & 0.4 \\
\hline \multicolumn{11}{|c|}{ Age at diagnosis of first cancer (years) } \\
\hline $\begin{array}{l}<1 \\
1-4 \\
5-9 \\
10-14 \\
15-19 \\
20-24\end{array}$ & $\begin{array}{r}188 \\
802 \\
555 \\
631 \\
1043 \\
2010\end{array}$ & \begin{tabular}{r|}
3.6 \\
15.3 \\
10.6 \\
12.1 \\
19.9 \\
38.4
\end{tabular} & $\begin{array}{r}3203 \\
7495 \\
6851 \\
6759 \\
10748 \\
17239\end{array}$ & $\begin{array}{r}10.6 \\
5.1 \\
6.3 \\
4.7 \\
3.5 \\
2.4\end{array}$ & $\begin{array}{r}10.3 \\
5.0 \\
6.1 \\
4.6 \\
3.4 \\
2.4\end{array}$ & $\begin{array}{r}11.0 \\
5.3 \\
6.4 \\
4.8 \\
3.6 \\
2.5\end{array}$ & $\begin{array}{r}0 \\
761 \\
374 \\
1572 \\
908 \\
2016\end{array}$ & $\begin{array}{l}0.0 \\
1.0 \\
0.4 \\
1.0 \\
0.3 \\
0.3\end{array}$ & $\begin{array}{l}- \\
0.9 \\
0.4 \\
0.9 \\
0.2 \\
0.3\end{array}$ & $\begin{array}{l}- \\
1.0 \\
0.5 \\
1.0 \\
0.3 \\
0.3\end{array}$ \\
\hline \multicolumn{11}{|l|}{ Sex } \\
\hline $\begin{array}{l}\text { Male } \\
\text { Female }\end{array}$ & $\begin{array}{l}2762 \\
2467\end{array}$ & $\begin{array}{l}52.8 \\
47.2\end{array}$ & $\begin{array}{l}26937 \\
25358\end{array}$ & $\begin{array}{l}3.5 \\
3.7\end{array}$ & $\begin{array}{l}3.5 \\
3.7\end{array}$ & $\begin{array}{l}3.6 \\
3.8\end{array}$ & $\begin{array}{l}2887 \\
2744\end{array}$ & $\begin{array}{l}0.3 \\
0.6\end{array}$ & $\begin{array}{l}0.3 \\
0.5\end{array}$ & $\begin{array}{l}0.3 \\
0.6\end{array}$ \\
\hline \multicolumn{11}{|l|}{ Carstairs deprivation fifth } \\
\hline $\begin{array}{l}1 \text {-Least deprived } \\
2 \\
3 \\
4 \\
5-\text { Most deprived }\end{array}$ & $\begin{array}{l}1087 \\
1005 \\
1040 \\
1055 \\
1036\end{array}$ & $\begin{array}{l}20.8 \\
19.2 \\
19.9 \\
20.2 \\
19.8\end{array}$ & $\begin{array}{r}9220 \\
11050 \\
10722 \\
10123 \\
11170\end{array}$ & $\begin{array}{l}3.0 \\
3.8 \\
3.7 \\
3.5 \\
4.1\end{array}$ & $\begin{array}{l}3.0 \\
3.8 \\
3.7 \\
3.4 \\
4.0\end{array}$ & $\begin{array}{l}3.1 \\
3.9 \\
3.8 \\
3.6 \\
4.2\end{array}$ & $\begin{array}{r}1499 \\
1203 \\
1221 \\
783 \\
925\end{array}$ & $\begin{array}{l}0.5 \\
0.4 \\
0.4 \\
0.3 \\
0.3\end{array}$ & $\begin{array}{l}0.5 \\
0.4 \\
0.4 \\
0.3 \\
0.3\end{array}$ & $\begin{array}{l}0.5 \\
0.5 \\
0.5 \\
0.3 \\
0.4\end{array}$ \\
\hline \multicolumn{11}{|l|}{ Follow-up time (years) } \\
\hline $\begin{array}{l}\geqslant 5,<10 \\
\geqslant 10,<15 \\
\geqslant 15,<20 \\
\geqslant 20\end{array}$ & $\begin{array}{l}1195 \\
1242 \\
1162 \\
1630\end{array}$ & $\begin{array}{l}22.9 \\
23.8 \\
22.2 \\
31.2\end{array}$ & $\begin{array}{l}11816 \\
10309 \\
10711 \\
19459\end{array}$ & $\begin{array}{r}20.1 \\
5.7 \\
3.4 \\
2.2\end{array}$ & $\begin{array}{r}19.8 \\
5.6 \\
3.3 \\
2.2\end{array}$ & $\begin{array}{r}20.5 \\
5.9 \\
3.4 \\
2.3\end{array}$ & $\begin{array}{r}137 \\
1065 \\
1921 \\
2508\end{array}$ & $\begin{array}{l}0.3 \\
0.7 \\
0.6 \\
0.3\end{array}$ & $\begin{array}{l}0.3 \\
0.6 \\
0.6 \\
0.3\end{array}$ & \begin{tabular}{|l|}
0.4 \\
0.7 \\
0.6 \\
0.3
\end{tabular} \\
\hline \multicolumn{11}{|l|}{ Type of first cancer } \\
\hline Leukaemias & 884 & 16.9 & 11034 & 6.3 & 6.2 & 6.4 & 1176 & 0.8 & 0.8 & 0.9 \\
\hline Lymphomas & 980 & 18.7 & 8775 & 2.8 & 2.8 & 2.9 & 571 & 0.2 & 0.2 & 0.2 \\
\hline CNS tumours & 587 & 11.2 & 10783 & 7.9 & 7.8 & 8.1 & 1678 & 1.3 & 1.2 & 1.3 \\
\hline Neuroblastoma & 93 & 1.8 & 903 & 5.2 & 4.9 & 5.6 & 0 & 0.0 & - & - \\
\hline Retinoblastoma & 81 & 1.5 & 825 & 4.7 & 4.4 & 5.0 & 0 & 0.0 & - & - \\
\hline Renal tumours & 154 & 2.9 & 1811 & 5.8 & 5.6 & 6.1 & 456 & 2.3 & 2.1 & 2.5 \\
\hline Hepatic tumours & 19 & 0.4 & 339 & 11.4 & 10.2 & 12.7 & 0 & 0.0 & - & - \\
\hline Bone tumours & 188 & 3.6 & 2216 & 4.6 & 4.4 & 4.8 & 194 & 0.4 & 0.3 & 0.4 \\
\hline Soft tissue sarcomas & 317 & 6.1 & 3311 & 4.1 & 4.0 & 4.3 & 46 & 0.1 & 0.0 & 0.1 \\
\hline Germ cell tumours & 694 & 13.3 & 4495 & 1.9 & 1.9 & 2.0 & 386 & 0.1 & 0.1 & 0.2 \\
\hline Melanoma and skin carcinomas & 709 & 13.6 & 2593 & 1.3 & 1.2 & 1.3 & 313 & 0.2 & 0.1 & 0.2 \\
\hline Other carcinomas & 459 & 8.8 & 3480 & 2.2 & 2.1 & 2.3 & 418 & 0.3 & 0.3 & 0.3 \\
\hline Other and unspecified neoplasms & 64 & 1.2 & 1730 & 5.6 & 5.3 & 5.8 & 393 & 1.3 & 1.2 & 1.5 \\
\hline
\end{tabular}

Table 2 shows, for selected primary cancers, SHRs for broad diagnostic categories based on the acute hospital discharge data. For all primary cancers combined, and for all subsequent diagnoses combined, the SHR was 2.8 (2.7-2.9), corresponding to an AER of 6.4 (6.0-6.6) hospital admissions per 100 cancer survivors per year (observed rate 9.9 and expected rate 3.5). Standardised hospitalisation ratios were significantly increased for most diagnostic categories, including neoplasms (disease recurrences and subsequent primaries combined). Of particular note, high SHRs are seen for endocrine disease (including diabetes mellitus) in patients with a history of leukaemia or CNS tumours; for diseases of the nervous system in patients with CNS tumours, leukaemia, or soft tissue sarcomas; for diseases of the circulatory system in patients with leukaemia and bone tumours (as well as specifically cardiomyopathy following leukaemia and soft tissue sarcoma, and cerebrovascular disease following leukaemia and CNS tumours); for diseases of the respiratory system in patients with leukaemia; for congenital malformations in patients with CNS tumours and soft tissue sarcoma; and for external causes in patients with bone tumours.

Figures 1 and 2 show, respectively, for all 5-year survivors, the cumulative incidence of diseases of the respiratory system and external causes of morbidity and mortality by deprivation fifth. The cumulative incidence of both of these broad categories of 
Table 2. Standardised hospitalisation ratios (SHR) among 5-year survivors of childhood, adolescent, or young adult cancer (based on acute hospital discharge data)

\section{Primary cancer}

\begin{tabular}{|c|c|c|c|c|c|c|c|c|c|c|}
\hline \multicolumn{2}{|c|}{ All cancers } & \multicolumn{2}{|c|}{ Leukaemia } & \multicolumn{2}{c|}{ Lymphoma } & \multicolumn{2}{c|}{ CNS } & \multicolumn{2}{c|}{ Bone } & Soft tissue sarcoma \\
\hline & & $95 \% \mathrm{Cl}$ & & $95 \% \mathrm{Cl}$ & & $95 \% \mathrm{Cl}$ & & $95 \% \mathrm{Cl}$ & $95 \% \mathrm{Cl}$ & $95 \% \mathrm{Cl}$ \\
\hline
\end{tabular}

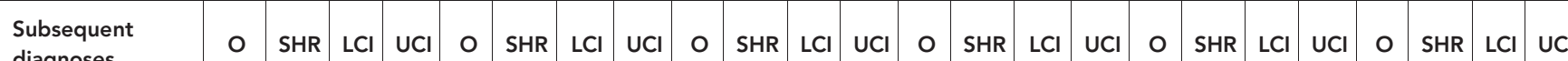

diagnoses

All diagnoses

combined

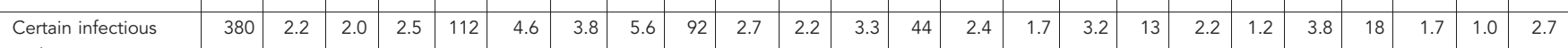

and parasitic

diseases

Neoplasms

Endocrine,

nutritional, and

metabolic diseases

Diabetes mellitus

Diseases of the

nervous system

Diseases of the

circulatory system

Coronary heart

disease

Cardiomyopathy

Cerebrovascular

disease

Diseases of the

respiratory system

Diseases of the

digestive system

Diseases of the

genitourinary

system

Congenital

malformations,

deformations and

chromosomal

abnormalities

Injury, poisoning

and certain other

consequences of

external causes

External causes of

morbidity and

mortality

Suicide, intentional

self-harm and

undetermined intent

Accidental

poisoning

All other accidents

Other causes

\begin{tabular}{|l|l|l|l|l|l|l|l|l|l|l|l|l|l|l|l|l|l|l|l|l|l|l|l|}
1252 & 8.1 & 7.7 & 8.6 & 288 & 21.0 & 18.6 & 23.6 & 221 & 6.6 & 5.8 & 7.5 & 211 & 16.9 & 14.7 & 19.3 & 51 & 10.3 & 7.6 & 13.5 & 92 & 11.6 & 9.4 & 14.2 \\
\hline
\end{tabular}

\begin{tabular}{|l|l|l|l|l|l|l|l|l|l|l|l|l|l|l|l|l|l|l|l|l|l|l|l|}
408 & 4.3 & 3.8 & 4.7 & 108 & 10.9 & 9.0 & 13.2 & 72 & 3.5 & 2.7 & 4.4 & 84 & 10.7 & 8.6 & 13.3 & 12 & 4.0 & 2.1 & 6.9 & 17 & 3.3 & 1.9 & 5.3
\end{tabular}

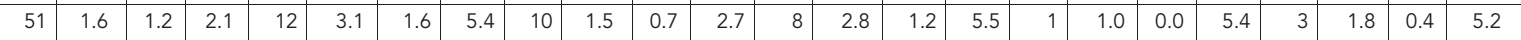

(2)

\begin{tabular}{|l|l|l|l|l|l|l|l|l|l|l|l|l|l|l|l|l|l|l|l|l|l|}
353 & 2.9 & 2.6 & 3.2 & 43 & 3.1 & 2.2 & 4.1 & 39 & 1.5 & 1.0 & 2.0 & 149 & 15.5 & 13.2 & 18.3 & 8 & 2.0 & 0.9 & 3.9 & 21 & 3.1 \\
\hline
\end{tabular}

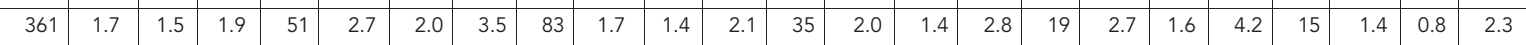

\begin{tabular}{r|r|r|r|r|r|r|r|r|r|r|r|r|r|r|}
\hline 28 & 1.4 & 1.0 & 2.1 & 1 & 1.2 & 0.0 & 6.7 & 18 & 3.6 & 2.1 & 5.6 & 0 & 0.0 &
\end{tabular}

\begin{tabular}{l|l|l|l|l|l}
3.4 & 0 & 0.0
\end{tabular}

\begin{tabular}{r|r|r|r|r|r|r|r|r|r|r|r|r|r|r|r|r|} 
& & & & & & & & & & & & & & \\
13 & 5.3 & 2.8 & 9.0 & 7 & 32.4 & 13.0 & 66.7 & 2 & 3.4 & 0.4 & 12.2 & 0 & 0.0 &
\end{tabular}

\begin{tabular}{l|l|l|l|l|l|l|l|l|l}
18.7 & 1 & 12.4 & 0.3 & 69.2 & 2 & 17.8 & 2.2 & 64.2 \\
\hline
\end{tabular}

\begin{tabular}{|l|l|l|l|l|l|l|l|l|l|l|l|l|l|l|l|l|l|l|l|l|l|l|l}
36 & 2.6 & 1.8 & 3.5 & 7 & 6.7 & 2.7 & 13.7 & 3 & 0.9 & 0.2 & 2.6 & 12 & 11.9 & 6.2 & 20.8 & 0 & 0.0 & & 8.0 & 2 & 3.2 & 0.4 & 11.4
\end{tabular}

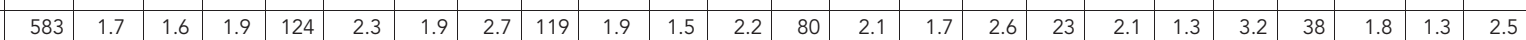

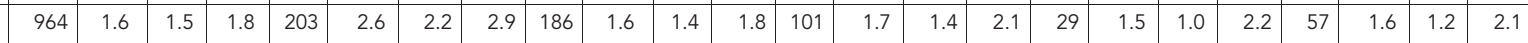

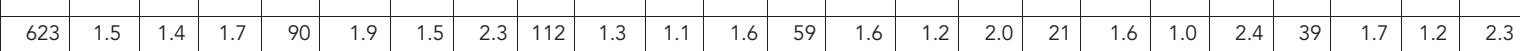

Abbreviations: $\mathrm{LCl} / \mathrm{UCl}=$ lower/upper $95 \%$ confidence interval; $\mathrm{O}=$ observed numbers of cases; $\mathrm{SHR}=$ standardised hospitalisation ratio

disease was significantly higher among the most compared with the least deprived fifth of the population $(P<0.001)$ with divergence over time.

In relation to psychiatric hospitalisation, the study cohort experienced 5631 bed days, corresponding to an SBDR of 0.4 (0.4-0.4). Although lower than expected compared with the Scottish population, SBDRs were higher in females than in males, in patients from less deprived areas of residence, and during the second decade of follow-up. They were higher than expected in patients originally diagnosed with CNS tumours (1.3, 1.2-1.3), renal tumours $(2.3,2.1-2.5)$, and other and unspecified neoplasms $(1.3,1.2-1.5)$ (Table 1).

Table 3 shows, for all primary cancers combined and for CNS tumours, SHRs for broad diagnostic categories based on the 


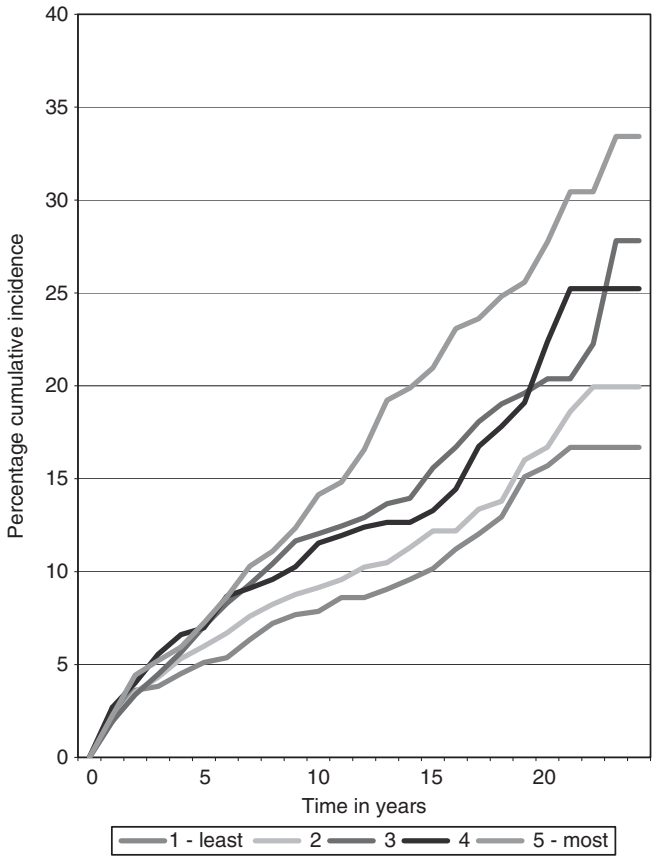

Figure 1. Cumulative incidence of diseases of the respiratory system (ICD-10 J00-J99) among survivors from date of 5-year survival, by deprivation fifth.

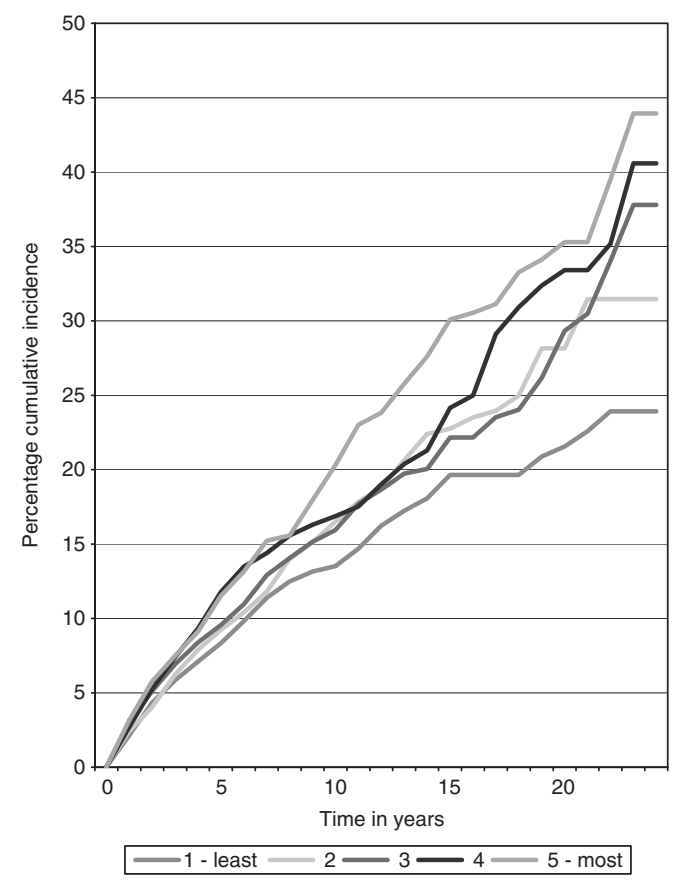

Figure 2. Cumulative incidence of external causes of morbidity and mortality (ICD-10 V01-Y98) among survivors from date of 5-year survival, by deprivation fifth.

psychiatric hospitalisation data. For all primary cancers combined, and for all subsequent diagnoses combined, the SHR was 0.9 (0.8-1.2). Overall, there were no significantly increased SHRs for any category of mental illness diagnostic group recorded during hospitalisation. However, for patients with a history of CNS tumours, higher than expected SHRs were seen for organic mental disorders, such as 'subacute confusional state' (12.8, 3.5-32.6).

\section{DISCUSSION}

We have shown that 5-year survivors of cancer diagnosed before the age of 25 years remain at increased risk of admission to acute hospitals and of spending more time in hospital than the general population of similar age and sex. However, the AER of hospital admission is low, reflecting relatively low background risks of hospitalisation among young people. Increased risks of hospitalisation with specific conditions are largely consistent with established late effects of cancer and its treatment (Scottish Intercollegiate Guidelines Network, 2013; Wallace et al, 2013). The risk of spending time in hospital seems particularly high among survivors of cancer diagnosed at a very young age. This may reflect the patterns of cancers diagnosed in this age group, which determines the intensity of therapy and its impact on child growth and development. In contrast, members of our study population were not at higher risk of admission to psychiatric hospital, and they spent significantly less time as psychiatric in-patients than the population as a whole. However, patients with a history of CNS tumours spent more time than expected in psychiatric hospital.

Our study has a number of strengths. In Scotland, the National Health Service (NHS) is funded by taxation and free at the point of use. The absence of barriers to treatment, such as charges, means that we expect to have identified most hospital in-patient-related morbidity from routinely collected data. Thus, while our study focuses on the more severe end of the spectrum of diseases leading to hospitalisation, it can nevertheless be regarded as effectively population based. As such, it is not subject to some of the biases associated with self-reporting (Taylor et al, 2010), non-participation (Mulrooney et al, 2009), and studies from specialist centres (Ness et al, 2009).

Scottish Cancer Registry data have been shown to be of comparatively high quality (Brewster et al, 1997, 2002) and record linkage between routinely collected NHS and mortality records is believed to be highly accurate and complete (Kendrick and Clarke, 1993; Kendrick, 1997). Hospitalisation data are supported by an active programme of quality assurance including regular assessments of data quality. In relation to discharges from acute hospitals, the accuracy of coding of main diagnosis has been estimated to be around $88 \%$ overall and has been relatively stable for around 20 years (Information Services Division, 2012).

Compared with analyses using mortality data, hospitalisation data yield more events occurring sooner (for example, during follow-up, there were 13 incident cases of cardiomyopathy compared with only two deaths). Unlike many other studies, it was possible to standardise our analyses for socio-economic deprivation at the time of cancer diagnosis, although this made little difference to the results. This could reflect limitations of the area-based indicator of deprivation that we used (Morris and Carstairs, 1991).

Our study also has a number of limitations. The fact that the outcomes assessed are based on hospitalisation means that we have not been able to identify and quantify less serious morbidity which may nevertheless be important to patients (Taylor et al, 2010). Admissions to private hospitals will not have been captured, although the use of private health services by the age group being studied is very low. The absence of comprehensive information on cancer treatment means that it is not possible to associate specific sequelae with specific modalities of therapy. Our study population and duration of follow-up are smaller than in some other studies, which limit the capacity to carry out subgroup analyses. At the same time, the application of multiple tests of statistical 


\begin{tabular}{|c|c|c|c|c|c|c|c|c|}
\hline \multirow[b]{4}{*}{ Psychiatric diagnosis } & \multicolumn{8}{|c|}{ Primary cancer } \\
\hline & \multicolumn{4}{|c|}{ All cancers } & \multicolumn{4}{|c|}{ CNS } \\
\hline & \multirow[b]{2}{*}{ O } & \multirow[b]{2}{*}{ SHR } & \multicolumn{2}{|c|}{$95 \% \mathrm{Cl}$} & \multirow[b]{2}{*}{ O } & \multirow[b]{2}{*}{ SHR } & \multicolumn{2}{|c|}{$95 \% \mathrm{Cl}$} \\
\hline & & & $\mathrm{LCl}$ & $\mathrm{UCl}$ & & & $\mathrm{LCl}$ & $\mathrm{UCl}$ \\
\hline Mental and behavioural disorders (All diagnoses) & 87 & 0.9 & 0.8 & 1.2 & 12 & 1.3 & 0.7 & 2.3 \\
\hline Organic, including symptomatic mental disorders & 7 & 1.9 & 0.8 & 3.8 & 4 & 12.8 & 3.5 & 32.6 \\
\hline Mental and behavioural disorders due to psychoactive substance use & 30 & 0.7 & 0.5 & 1.1 & 2 & 0.5 & 0.1 & 1.9 \\
\hline Schizophrenia, schizotypal and delusional disorders & 25 & 1.1 & 0.7 & 1.6 & 6 & 2.5 & 0.9 & 5.5 \\
\hline Mood (affective) disorders & 36 & 0.8 & 0.6 & 1.2 & 4 & 1.0 & 0.3 & 2.6 \\
\hline Neurotic, stress-related and somatoform disorders & 18 & 0.8 & 0.5 & 1.2 & 1 & 0.5 & 0.0 & 2.5 \\
\hline Behavioural syndromes associated with physiological disturbances and physical factors & 1 & 0.3 & 0.0 & 1.7 & 0 & 0.0 & - & - \\
\hline Disorders of adult personality and behaviour & 7 & 0.6 & 0.2 & 1.2 & 0 & 0.0 & - & - \\
\hline Mental retardation & 4 & 0.6 & 0.2 & 1.4 & 2 & 3.0 & 0.4 & 10.7 \\
\hline Disorders of psychological development & 1 & 0.8 & 0.0 & 4.2 & 0 & 0.0 & - & - \\
\hline Behavioural and emotional disorders with onset usually occurring in childhood and adolescence & 0 & 0.0 & - & - & 0 & 0.0 & - & - \\
\hline Unspecified mental disorder & 0 & 0.0 & - & - & 0 & 0.0 & - & - \\
\hline
\end{tabular}

Abbreviations: $\mathrm{Cl}=$ confidence interval; $\mathrm{CNS}=$ central nervous system; $\mathrm{LCl} / \mathrm{UCl}=$ lower/upper $95 \%$ confidence interval; $\mathrm{O}=$ observed numbers of cases.

significance has increased the risk of a type I error (spurious statistically significant findings). Finally, some members of the cohort may have emigrated from Scotland without this being recorded and are therefore lost to follow-up, but we believe that the proportion of unrecorded emigrations from the cohort is low.

We are only aware of one study (in British Columbia) that has used non-psychiatric hospitalisation data to investigate late effects of cancer in early life (Bradley et al, 2010; McBride et al, 2010; Lorenzi et al, 2011), although a similar study is planned in England (Hawkins, 2010). The British Columbia study has shown higher rates of hospitalisation among survivors of cancer diagnosed below the age of 20 years (Bradley et al, 2010), with risks varying by type of primary cancer, but highest subsequent risks for neoplasms (including second primary cancers) (Lorenzi et al, 2011). Although the US Childhood Cancer Survivor Study cohort has also reported higher than expected hospitalisation rates, their results were based on the self-reported data and were subject to incomplete participation (Kurt et al, 2012).

We are only aware of a single study (in Denmark) that used cancer registration data linked to routine psychiatric hospitalisation data to investigate psychiatric hospitalisations among survivors of cancer in childhood or adolescence (Ross et al, 2003). The authors found no evidence of an increased risk of admission except among survivors of brain tumours, which is consistent, in part, with our own findings. However, a recent update of the Danish study showed an increased risk of hospital contact for mental disorders, especially in children younger than 10 years at diagnosis, and in survivors of CNS tumours, haematological malignancies, and solid tumours (Lund et al, 2013). Despite these findings, the fact that psychosocial sequelae of childhood cancer are well recognised (Recklitis et al, 2010; Brinkman et al, 2013), and that antidepressant use has been shown to be higher among survivors of childhood, adolescent, and young adult cancer in British Columbia (Deyell et al, 2013), our data suggest an overall lower risk of serious psychiatric morbidity leading to in-patient admissions. This may reflect an inadequate period of follow-up, or it may indicate that survivors of cancer at a young age develop resilience and a degree of resistance to serious mental illness. At the same time, the SHR for all mental and behavioural disorders combined was not significantly lower than expected, suggesting that the lower SBDR is a reflection of case mix.

In relation to some of our specific findings, the increased risk of neoplasms was expected, especially as this category included admissions for recurrence of the originally diagnosed cancer, as well as for subsequent independent primary cancers. Recurrent disease accounts for part of the total burden of hospitalisations for cancer survivors, whereas at least a proportion of new primary cancers are likely to represent late effects of treatment.

An increased risk of subsequent diabetes mellitus has been associated previously with total body irradiation, abdominal irradiation, cranial irradiation (though not after adjustment in a multivariable model), use of alkylating agents, and younger age at diagnosis (Meacham et al, 2009). Although diabetes is known to be poorly recorded in hospital admission data for adults (Anwar et al, 2011), we think it highly unlikely that differential completeness of reporting between cohort members and the general population would have influenced our finding of higher ratios for hospitalisation with diabetes among cancer survivors than among the general population.

The cardiotoxic effects of radiation therapy to the chest and some chemotherapy agents are well established (van der Pal et al, 2012; Lipshultz et al, 2013). The particularly high SHRs for cardiomyopathy that we found in survivors of leukaemia and soft tissue sarcoma seem most likely to be related to past exposure to anthracycline-based therapy.

Although, in our acute hospitalisation analysis, the overall SHR for suicide, intentional self-harm, and undetermined intent is significantly higher than expected $(4.3,95 \%$ confidence interval 3.6-5.2), in our previously published analysis of mortality data, the standardised mortality ratio for suicide was not significantly increased (SMR 1.1, 95\% confidence interval 0.6-2.0) (Brewster et al, 2013). These findings are consistent with other studies. For example, in a 
recent study based on the US Childhood Cancer Survivor Study cohort, adult survivors were found to be significantly more likely to have suicide ideation than a group of non-cancer controls. Suicide ideation was strongly associated with survivors' physical health, even many years after the completion of therapy and when the effects of cancer diagnosis, treatment, and depression had been taken into account (Recklitis et al, 2010). In contrast, the majority of large, population-based studies have not shown an increased risk of death by suicide among survivors of childhood cancer (Hawkins et al, 2007).

Associations between congenital anomalies and/or genetic factors and childhood cancer have been established in many studies (Little, 1999). Specific associations include Li-Fraumeni syndrome and soft tissue sarcoma, CNS tumours, leukaemia, osteosarcoma, and adrenocortical carcinoma. In addition, neurofibromatosis has been associated with CNS tumours (although note that neurofibromatosis was classified as a neoplasm of uncertain behaviour in ICD-9; not until the introduction of ICD-10 (April 1996 for hospital data in Scotland) was it classified under congenital malformations). Although we found increased risks of hospitalisation with congenital malformations in all patients and especially those with a history of leukaemia, CNS tumours, and soft tissue sarcoma, it is important to bear in mind that some abnormalities could be secondary to the cancer (for example, hydrocephalus due to brain tumour).

Widening socio-economic inequalities in cumulative incidence of admissions for respiratory diseases and external causes may reflect, respectively, socio-economic patterning of smoking prevalence (Austin et al, 2005; Scottish Public Health Observatory, 2009) and of intentional self-harm and injuries of undetermined intent (Leyland et al, 2007) among young people that are already well recognised.

In summary, our study has shown that long-term survivors of cancer in childhood and young adulthood are at higher risk of subsequent admission to acute hospitals, but not psychiatric hospitals, compared with the general population. However, the absolute risk of admission to acute hospitals is low. Our study has also demonstrated the utility of routinely collected, linked hospitalisation records for high level monitoring of many serious, though not necessarily fatal late effects at a relatively low cost. Long-term clinical follow-up of survivors of childhood cancer should focus on the prevention and treatment of the late effects of cancer in those patients at highest risk of hospitalisation (Wallace et al, 2001; Edgar et al, 2013). Late effects related to treatment for cancer may occur soon after treatment is completed, or may not become apparent for many years or decades. Lifelong follow-up of survivors is recommended as a current best practice (Scottish Intercollegiate Guidelines Network, 2013; Wallace et al, 2013) and this will necessitate multidisciplinary collaboration between patients and their families, oncologists and other health professionals, including those in primary care to ensure early diagnosis, counselling and, where possible, timely initiation of appropriate treatments.

\section{ACKNOWLEDGEMENTS}

This work was supported by a grant from the Chief Scientist Office, Scottish Government Health Directorate (CZG/2/508).

\section{CONFLICT OF INTEREST}

The authors declare no conflict of interest.

\section{REFERENCES}

Anwar H, Fischbacher CM, Leese GP, Lindsay RS, McKnight JA, Wild SH Scottish Diabetes Research Network Epidemiology Group (2011) Assessment of the under-reporting of diabetes in hospital admission data: a study from the Scottish Diabetes Research Network Epidemiology Group. Diabet Med 28: 1514-1519.

Austin JB, Selvaraj S, Godden D, Russell G (2005) Deprivation, smoking, and quality of life in asthma. Arch Dis Child 90: 253-257.

Bhatia S, Constine LS (2009) Late morbidity after successful treatment of children with cancer. Cancer J 15: 174-180.

Birch JM, Alston RD, Kelsey AM, Quinn MJ, Babb P, McNally RJQ (2002) Classification and incidence of cancers in adolescents and young adults in England 1979-1997. Br J Cancer 87: 1267-1274.

Bradley NM, Lorenzi MF, Abanto Z, Sheps S, Broemeling AM, Spinelli JJ, Goddard K, Pritchard S, Rogers P, McBride ML. CAYACS Research Group (2010) Hospitalisations 1998-2000 in a British Columbia population-based cohort of young cancer survivors: report of the Childhood/Adolescent/Young Adult Cancer Survivors (CAYACS) Research Program. Eur J Cancer 46: 2441-2448.

Brewster DH, Clark D, Hopkins L, Bauer J, Wild SH, Edgar AB, Wallace WH (2013) Subsequent mortality experience in five-year survivors of childhood, adolescent and young adult cancer in Scotland: a population based, retrospective cohort study. Eur J Cancer 49: 3274-3283.

Brewster D, Crichton J, Harvey JC, Dawson G (1997) Completeness of case ascertainment in a Scottish Regional Cancer Registry for the year 1992. Public Health 111: 339-343.

Brewster DH, Stockton D, Harvey J, Mackay M (2002) Reliability of cancer registration data in Scotland, 1997. Eur J Cancer 38: 414-417.

Brinkman TM, Zhu L, Zeltzer LK, Recklitis CJ, Kimberg C, Zhang N, Muriel AC, Stovall M, Srivastava DK, Robison LL, Krull KR (2013) Longitudinal patterns of psychological distress in adult survivors of childhood cancer. Br J Cancer 109: 1373-1381.

Deyell RJ, Lorenzi M, Ma S, Rassekh SR, Collet JP, Spinelli JJ, McBride ML (2013) Antidepressant use among survivors of childhood, adolescent and young adult cancer: a report of the Childhood, Adolescent and Young Adult Cancer Survivor (CAYACS) Research Program. Pediatr Blood Cancer 60: 816-822.

Edgar AB, Morris EM, Kelnar CJ, Wallace WH (2009) Long-term follow-up of survivors of childhood cancer. Endocr Dev 15: 159-180.

Edgar AB, Duffin K, Borthwick S, Marciniak-Stepak P, Wallace WH (2013) Can intensity of long-term follow-up for survivors of childhood and teenage cancer be determined by therapy-based risk-stratification? $B M J$ Open 3(8): pii: e002451.

Hawkins MM, Mertens AC, Möller TR, Garwicz S (2007) Suicide among survivors of childhood cancer. J Clin Oncol 25: 731-732.

Hawkins MM (2010) Survivorship outcomes research based on record linkage. Pediatr Blood Cancer 55: 224-225.

Information Services Division (2012) Assessment of SMR01 Data 2010-2011. Scotland Report May 2012. Available at http://www.isdscotland.org/ Health-Topics/Hospital-Care/Publications/2012-05-08/Assessment-ofSMR01Data-2010-2011-ScotlandReport.pdf (accessed 28th October 2013).

Kendrick S, Clarke J (1993) The Scottish record linkage system. Health Bull (Edinb) 51: 72-79.

Kendrick S (1997) The Development of Record Linkage in Scotland: The Responsive Application of Probability Matching. In Record Linkage Techniques - 1997: Proceedings of an International Workshop and Exposition, Arlington, VA, 20-21 March 1997, Alvey W, Jamerson B (eds). Chapter 10, pp 319-332. Federal Committee on Statistical Methodology, Office of Management and Budget: Washington DC.

Kurt BA, Nolan VG, Ness KK, Neglia JP, Tersak JM, Hudson MM, Armstrong GT, Hutchinson RJ, Leisenring WM, Oeffinger KC, Robison LL, Arora M (2012) Hospitalization rates among survivors of childhood cancer in the Childhood Cancer Survivor Study cohort. Pediatr Blood Cancer 59: 126-132.

Leyland AH, Dundas R, McLoone P, Boddy FA (2007) Cause-specific inequalities in mortality in Scotland: two decades of change. A populationbased study. BMC Public Health 7: 172.

Lipshultz SE, Cochran TR, Franco VI, Miller TL (2013) Treatment-related cardiotoxicity in survivors of childhood cancer. Nat Rev Clin Oncol 10: $697-710$.

Little J (1999) Epidemiology of Childhood Cancer. IARC Scientific Publications No. 149. International Agency for Research on Cancer: Lyon. 
Lorenzi MF, Xie L, Rogers PC, Pritchard S, Goddard K, McBride ML (2011) Hospital-related morbidity among childhood cancer survivors in British Columbia, Canada: report of the childhood, adolescent, young adult cancer survivors (CAYACS) program. Int J Cancer 128: 1624-1631.

Lund LW, Winther JF, Dalton SO, Cederkvist L, Jeppesen P, Deltour I, Hargreave M, Kjær SK, Jensen A, Rechnitzer C, Andersen KK, Schmiegelow K, Johansen C (2013) Hospital contact for mental disorders in survivors of childhood cancer and their siblings in Denmark: a population-based cohort study. Lancet Oncol 14: 971-980.

McBride ML, Rogers PC, Sheps SB, Glickman V, Broemeling AM, Goddard K, Hu J, Lorenzi M, Peacock S, Pritchard S, Rassekh SR, Siegel L, Spinelli JJ, Teckle P, Xie L (2010) Childhood, adolescent, and young adult cancer survivors research program of British Columbia: objectives, study design, and cohort characteristics. Pediatr Blood Cancer 55: 324-330.

Meacham LR, Sklar CA, Li S, Liu Q, Gimpel N, Yasui Y, Whitton JA, Stovall M, Robison LL, Oeffinger KC (2009) Diabetes mellitus in long-term survivors of childhood cancer. Increased risk associated with radiation therapy: a report for the childhood cancer survivor study. Arch Intern Med 169: 1381-1388.

Morris R, Carstairs V (1991) Which deprivation? A comparison of selected deprivation indexes. J Public Health Med 13: 318-326.

Mulrooney DA, Yeazel MW, Kawashima T, Mertens AC, Mitby P, Stovall M, Donaldson SS, Green DM, Sklar CA, Robison LL, Leisenring WM (2009) Cardiac outcomes in a cohort of adult survivors of childhood and adolescent cancer: retrospective analysis of the Childhood Cancer Survivor Study cohort. BMJ 339: b4606.

Ness KK, Leisenring W, Goodman P, Kawashima T, Mertens AC, Oeffinger KC, Armstrong GT, Robison LL (2009) Assessment of selection bias in clinic-based populations of childhood cancer survivors: a report from the childhood cancer survivor study. Pediatr Blood Cancer 52: 379-386.

Recklitis CJ, Diller LR, Li X, Najita J, Robison LL, Zeltzer L (2010) Suicide ideation in adult survivors of childhood cancer: a report from the Childhood Cancer Survivor Study. J Clin Oncol 28: 655-661.

\section{APPENDIX 1}

Study Classification of Primary Neoplasm and Mappings from ICCC-3 and Teenagers and Young Adults with Cancer (TYAC) Classifications

Table A1: Study classification of primary neoplasm

\begin{tabular}{|l|}
\hline Study classification \\
\hline Leukaemias \\
\hline Lymphomas \\
\hline CNS tumours \\
\hline Neuroblastoma \\
\hline Retinoblastoma \\
\hline Renal tumours \\
\hline Hepatic tumours \\
\hline Bone tumours \\
\hline Soft tissue sarcomas \\
\hline Germ cell tumours \\
\hline Melanoma and skin carcinomas \\
\hline Other carcinomas* \\
\hline Other and unspecified neoplasms \\
\hline *Except renal, hepatic, gonadal, and skin. \\
\hline
\end{tabular}

Table A2: Mapping of Childhood Cancer Classification (ICCC-3) to Study Classification

\begin{tabular}{|l|l|}
\hline ICCC-3 classification & Study classification \\
\hline $\begin{array}{l}\text { Group I-Leukaemias, myeloproliferative dis- } \\
\text { eases, and myelodysplastic diseases }\end{array}$ & All Group I = Leukaemias \\
\hline $\begin{array}{l}\text { Group II-Lymphomas and reticuloendothelial } \\
\text { neoplasms }\end{array}$ & All Group II = Lymphomas \\
\hline
\end{tabular}

Ross L, Johansen C, Dalton SO, Mellemkjaer L, Thomassen LH, Mortensen PB, Olsen JH (2003) Psychiatric hospitalizations among survivors of cancer in childhood or adolescence. N Engl J Med 349: 650-657.

Scottish Intercollegiate Guidelines Network (2013) Long Term Follow-Up of Survivors of Childhood Cancer (SIGN 132). Scottish Intercollegiate Guidelines Network: Edinburgh.

Scottish Public Health Observatory (2009) Young Adult Smokers in Scotland. December 2008. Revised December 2009. Available at http://www.scotpho.org.uk/downloads/scotphoreports/scotpho081219_ youngadultsmokers_rep.pdf (accessed 28 October 2013).

Steliarova-Foucher E, Stiller C, Lacour B, Kaatsch P (2005) International Classification of Childhood Cancer, third edition. Cancer 103: 1457-1467.

Taylor N, Absolom K, Michel G, Urquhart T, Gerrard M, Jenkins A, Lee V, Vora A, Eiser C (2010) Comparison of self-reported late effects with medical records among survivors of childhood cancer. Eur J Cancer 46: 1069-1078.

van der Pal HJ, van Dalen EC, van Delden E, van Dijk IW, Kok WE, Geskus RB, Sieswerda E, Oldenburger F, Koning CC, van Leeuwen FE, Caron HN, Kremer LC (2012) High risk of symptomatic cardiac events in childhood cancer survivors. J Clin Oncol 30: 1429-1437.

Wallace WH, Blacklay A, Eiser C, Davies H, Hawkins M, Levitt GA, Jenney ME. Late Effects Committee of the United Kingdom Children's Cancer Study Group (UKCCSG) (2001) Developing strategies for long term follow up of survivors of childhood cancer. BMJ 323: 271-274.

Wallace WH, Thompson L, Anderson RA. Guideline Development Group (2013) Long term follow-up of survivors of childhood cancer: summary of updated SIGN guidance. BMJ 346: f1190.

This work is published under the standard license to publish agreement. After 12 months the work will become freely available and the license terms will switch to a Creative Commons AttributionNonCommercial-Share Alike 3.0 Unported License.

\begin{tabular}{|l|l|}
\hline (Continued) \\
\hline ICCC-3 classification & Study classification \\
\hline $\begin{array}{l}\text { Group III-CNS and miscellaneous intracranial } \\
\text { and intraspinal neoplasms }\end{array}$ & All Group III = CNS tumours \\
\hline $\begin{array}{l}\text { Group IV-Neuroblastoma and other peripheral } \\
\text { nervous cell tumours }\end{array}$ & $\begin{array}{l}\text { All Group } \\
\text { IV = Neuroblastoma }\end{array}$ \\
\hline Group V-Retinoblastoma & All Group V= Retinoblastoma \\
\hline Group VI-Renal tumours & All Group VI = Renal tumours \\
\hline Group VII-Hepatic tumours & $\begin{array}{l}\text { All Group VII = Hepatic } \\
\text { tumours }\end{array}$ \\
\hline Group VIII-Malignant bone tumours & $\begin{array}{l}\text { All Group VIII = Bone } \\
\text { tumours }\end{array}$ \\
\hline $\begin{array}{l}\text { Group IX-Soft tissue and other extraosseous } \\
\text { sarcomas }\end{array}$ & $\begin{array}{l}\text { All Group IX }=\text { Soft tissue } \\
\text { sarcomas }\end{array}$ \\
\hline $\begin{array}{l}\text { Group X-Germ cell tumours, trophoblastic } \\
\text { tumours, and neoplasms of gonads }\end{array}$ & $\begin{array}{l}\text { All Group X }=\text { Germ cell } \\
\text { tumours }\end{array}$ \\
\hline $\begin{array}{l}\text { Group XI-Other malignant epithelial neoplasms } \\
\text { and malignant melanomas }\end{array}$ & $\begin{array}{l}\text { Category XId = Melanoma } \\
\text { and skin carcinomas } \\
\text { Category XIe = Melanoma and } \\
\text { skin carcinomas } \\
\text { Remainder }=\text { Other } \\
\text { carcinomas }\end{array}$ \\
\hline $\begin{array}{l}\text { Group XII-Other and unspecified malignant } \\
\text { neoplasms }\end{array}$ & $\begin{array}{l}\text { All Group XII = Other and } \\
\text { unspecified neoplasms }\end{array}$ \\
\hline
\end{tabular}

Table A3: Mapping of TYAC Classification to Study Classification*

\begin{tabular}{|l|l|}
\hline TYAC classification & Study classification \\
\hline Group 1-Leukaemia & All Group 1=Leukaemias \\
\hline Group 2-Lymphoma & All Group 2=Lymphomas \\
\hline $\begin{array}{l}\text { Group 3-Central nervous system and other } \\
\text { intracranial and intraspinal neoplasms (CNS } \\
\text { tumours) }\end{array}$ & All Group 3=CNS tumours \\
\hline
\end{tabular}




\begin{tabular}{|c|c|}
\hline \multicolumn{2}{|l|}{ (Continued) } \\
\hline TYAC classification & Study classification \\
\hline $\begin{array}{l}\text { Group 4-Osseous and Chondromatous Neo- } \\
\text { plasms, Ewing tumour and other Neoplasms of } \\
\text { Bone (Bone Tumours) }\end{array}$ & All Group $4=$ Bone tumours \\
\hline Group 5-Soft tissue sarcomas (STS) & $\begin{array}{l}\text { All Group } 5=\text { Soft tissue } \\
\text { sarcomas }\end{array}$ \\
\hline $\begin{array}{l}\text { Group 6-Germ cell and trophoblastic neo- } \\
\text { plasms (Germ cell tumours) }\end{array}$ & All Group 6= Germ cell tumours \\
\hline Group 7-Melanoma and skin carcinoma & $\begin{array}{l}\text { All Group } 7=\text { Melanoma and } \\
\text { skin carcinomas }\end{array}$ \\
\hline Group 8-Carcinomas (except of skin) & $\begin{array}{l}\text { Category } 8.5 .1=\text { Renal tumours } \\
\text { Category } 8.5 .3=\text { Germ cell } \\
\text { tumours } \\
\text { Category } 8.6 .3=\text { Hepatic tumours } \\
\text { Remainder of Group } 8=\text { Other } \\
\text { carcinomas }\end{array}$ \\
\hline $\begin{array}{l}\text { Group 9-Miscellaneous specified neoplasms } \\
\text { NEC (Miscellaneous specified) }\end{array}$ & $\begin{array}{l}\text { Category } 9.1 .1=\text { Renal tumours } \\
\text { Category } 9.1 .2=\text { Neuroblastoma } \\
\text { Category } 9.2 .1=\text { Neuroblastoma } \\
\text { Category } 9.2 .2=\text { Germ cell } \\
\text { tumours } \\
\text { Category } 9.2 .3=\text { Lymphomas } \\
\text { Remainder of Group } 9=\text { Other } \\
\text { and unspecified neoplasms }\end{array}$ \\
\hline $\begin{array}{l}\text { Group 10-Unspecified malignant neoplasms } \\
\text { NEC (Unspecified) }\end{array}$ & $\begin{array}{l}\text { All Group } 10=\text { Other and } \\
\text { unspecified neoplasms }\end{array}$ \\
\hline \multicolumn{2}{|c|}{$\begin{array}{l}\text { *Any cases with ICDO morphology codes } 9510 / 3-9514 / 3=\text { Retinoblastoma. } \\
\text { *Any cases with ICDO morphology codes } 8970 / 3=\text { Hepatic tumours. } \\
\text { *Any cases with ICDO morphology codes } 8964 / 3=\text { Renal tumours. } \\
\text { *Any cases with ICDO morphology codes } 8963 / 3+\text { ICD9 } 189.0 \text { or ICD10 C64 = Renal tumours. } \\
\text { *Any remaining cases with ICDO morphology codes } 8963 / 3=\text { Soft tissue sarcomas. } \\
\text { *Any cases with ICDO morphology codes } 9501-9504+I C D 9191-192,237.5,237.6,237.9 \text { or } \\
\text { ICD10 C70.0-C72.9, D32-D33, D42-D43=CNS tumours. } \\
\text { *Any remaining cases with ICDO morphology codes } 9501 / 3-9504 / 3=\text { Neuroblastoma. } \\
\text { *Any cases with ICDO morphology codes } 9505-9508=\text { CNS tumours. } \\
\text { *Any cases with ICDO morphology codes } 9520 / 3-9523 / 3=\text { Neuroblastoma. }\end{array}$} \\
\hline
\end{tabular}

\section{APPENDIX 2}

Table A4: Disease-specific outcome codes from acute hospital discharge records (first occurrence, any mention)

\begin{tabular}{|l|l|l|}
\hline Disease grouping & ICD9 & ICD10 \\
\hline $\begin{array}{l}\text { Certain infectious and parasitic } \\
\text { diseases }\end{array}$ & $001-139$ & A00-B99 \\
\hline Neoplasms & $140-239$ & C00-D48 \\
\hline $\begin{array}{l}\text { Endocrine, nutritional and metabolic } \\
\text { diseases }\end{array}$ & $240-279$ & E00-E90 \\
\hline Diabetes mellitus & 250 & E10-E14 \\
\hline $\begin{array}{l}\text { Diseases of the nervous system } \\
\text { Diseases of the circulatory system }\end{array}$ & $320-359$ & $\begin{array}{l}\text { G00-G99 excluding } \\
\text { G45-G46 }\end{array}$ \\
\hline Coronary heart disease & $390-459$ & I00-I99, G45-G46 \\
\hline Cardiomyopathy & 425 & I20-I25 \\
\hline Cerebrovascular disease & $430-438$ & I60-I69, G45-G46 \\
\hline
\end{tabular}

\begin{tabular}{|c|c|c|}
\hline Disease grouping & ICD9 & ICD10 \\
\hline Diseases of the respiratory system & $460-519$ & J00-J99 \\
\hline $\begin{array}{l}\text { Interstitial pneumonitis and/or } \\
\text { pulmonary fibrosis caused by } \\
\text { radiation or drugs }\end{array}$ & 508 & $\mathrm{~J} 70$ \\
\hline Diseases of the digestive system & $520-579$ & K00-K93 \\
\hline Diseases of the genitourinary system & $580-629$ & N00-N99 \\
\hline $\begin{array}{l}\text { Congenital malformations, deforma- } \\
\text { tions and chromosomal abnormalities }\end{array}$ & $740-759$ & Q00-Q99 \\
\hline $\begin{array}{l}\text { Injury, poisoning and certain other } \\
\text { consequences of external causes }\end{array}$ & $800-999$ & S00-T98 \\
\hline $\begin{array}{l}\text { External causes of morbidity and } \\
\text { mortality }\end{array}$ & E800-E999 & V01-Y98 \\
\hline $\begin{array}{l}\text { Suicide, intentional self-harm and } \\
\text { injuries/events of undetermined } \\
\text { intent }\end{array}$ & $\begin{array}{l}\text { E950-E959, } \\
\text { E980-E989 }\end{array}$ & $\begin{array}{l}\text { X60-X84, Y87.0, Y10-Y34, } \\
\text { Y87.2 }\end{array}$ \\
\hline Accidental poisoning & E850-E869 & $\mathrm{X} 40-\mathrm{X} 49$ \\
\hline All other accidents & $\begin{array}{l}\text { E800-E849, } \\
\text { E870-E949 }\end{array}$ & 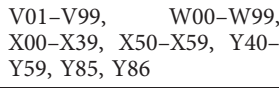 \\
\hline Other causes & & \\
\hline
\end{tabular}

Table A5: Disease-specific outcome codes from psychiatric hospitalisation records (first occurrence, any mention)

\begin{tabular}{|c|c|c|}
\hline Disease grouping & ICD10 & ICD9 \\
\hline $\begin{array}{l}\text { Mental and behavioural disor- } \\
\text { ders (All diagnoses) }\end{array}$ & F00-F99 & $290-319$ \\
\hline $\begin{array}{l}\text { Organic, including symptomatic } \\
\text { mental disorders }\end{array}$ & F00-F09 & $290,293,294,310$ \\
\hline $\begin{array}{l}\text { Mental and behavioural disor- } \\
\text { ders due to psychoactive sub- } \\
\text { stance use }\end{array}$ & F10-F19 & 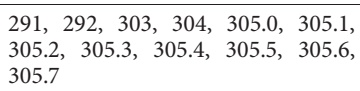 \\
\hline $\begin{array}{l}\text { Schizophrenia, schizotypal and } \\
\text { delusional disorders }\end{array}$ & F20-F29 & $295,297,298.3,298.4,298.9$ \\
\hline Mood (affective) disorders & F30-F39 & $296,298.0,298.1,300.4,301.1,311$ \\
\hline $\begin{array}{l}\text { Neurotic, stress-related and } \\
\text { somatoform disorders }\end{array}$ & F40-F48 & 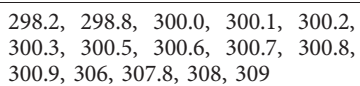 \\
\hline $\begin{array}{l}\text { Behavioural syndromes asso- } \\
\text { ciated with physiological distur- } \\
\text { bances and physical factors }\end{array}$ & F50-F59 & $\begin{array}{l}302.7,305.8,305.9,307.1,307.4 \text {, } \\
307.5,316\end{array}$ \\
\hline $\begin{array}{l}\text { Disorders of adult personality } \\
\text { and behaviour }\end{array}$ & F60-F69 & $\begin{array}{lllll}301.0, & 301.2, & 301.3, & 301.4, & 301.5, \\
301.6, & 301.7, & 301.8, & 301.9, & 302.1, \\
302.2, & 302.3, & 302.4, & 302.5, & 302.6 \\
302.8, & 302.9, & 312.2\end{array}$ \\
\hline Mental retardation & F70-F79 & $317,318,319$ \\
\hline $\begin{array}{l}\text { Disorders of psychological } \\
\text { development }\end{array}$ & F80-F89 & 299,315 \\
\hline $\begin{array}{l}\text { Behavioural and emotional } \\
\text { disorders with onset usually } \\
\text { occurring in childhood and } \\
\text { adolescence }\end{array}$ & F90-F98 & 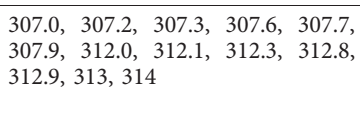 \\
\hline Unspecified mental disorder & F99 & \\
\hline
\end{tabular}

